

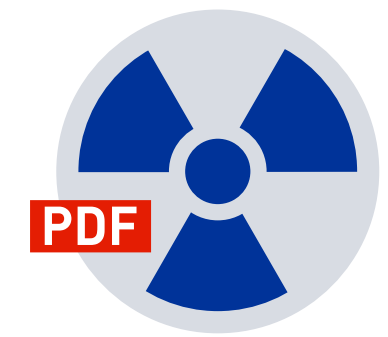

\section{REALOBJECTS PDFreactor $^{\oplus}$}

\section{Evaluation Version}

This PDF document was created by an evaluation version of RealObjects PDFreactor 10.2.10722. The evaluation version is fully functional, but includes this information page. It must not be used for production purposes. The information page and all other evaluation notices must not be removed from the PDF file.

NOTE: Conversions in evaluation mode might be slower and the results might have a larger file size than in production mode.

\section{Buy PDFreactor}

PDFreactor has detected 4 CPU cores, which means you need 1 license pack to use PDFreactor.

To buy a PDFreactor license follow this link:

\section{Buy PDFreactor online}

\section{About PDFreactor}

RealObjects PDFreactor is a powerful formatting processor for converting HTML and XML documents into PDF. It uses Cascading Style Sheets (CSS) to define page layout and styles. The server-side tool enables a great variety of applications in the fields of ERP, eCommerce and Electronic Publishing.

PDFreactor supports HTML5, CSS3 and JavaScript.

It allows you to dynamically generate PDF documents such as invoices, delivery notes and shipping documents on-the-fly. PDFreactor allows you to easily add server-based PDF generation functionality to your application or service. Since PDFreactor runs on a server, the end-user in general does not need any software other than a PDF viewer.

For more information visit www.pdfreactor.com 

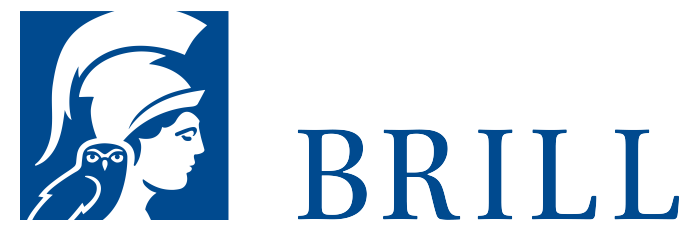

\title{
On Proclus and his Influence in Medieval Philosophy
}

\author{
Editors: E.P. Bos and P.A. Meijer
}

Proclus (c. $410-485$ ) was one of the major Greek philosophers of late Antiquity. In his metaphysics he developed and systematized fundamental problems of Plato's thought, such as participation; transcendence - immanence; causation participation - return; henads and monads. In a theological way he interpreted some of Plato's dialogues. In the tradition of the neo-platonic school of Athens he tried to bring together Orpheus, Pythagoras and Plato.

Before and after his works had been translated into Latin, Proclus influenced the Christian West through the Liber de causis ("Book of Causes"), a Latin translation of an anonymous Arab version of his Elementatio theologica. Among those who commented on the Liber or on some of its theses, were many well-known philosophers: Albert the Great, Thomas Aquinas, Master Eckhart, Berthold of Moosberg and William of Ockham. The Liber de causis stimulated discussions about the concepts of God, first and second causality, universals, metaphysics of being as opposed to metaphysics of the one.

In the volume various specialists discuss these problems: Saffrey, De Rijk, Meyer, Steel, De Libera, Aertsen, Beierwaltes and Bos.

Readership

Students and specialists of Ancient Philosophy

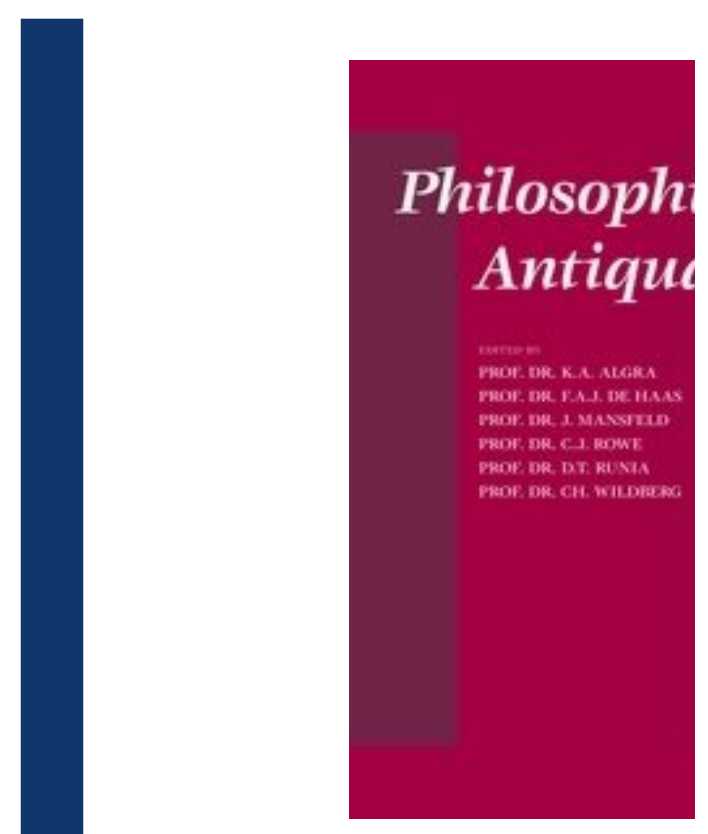

Pages: viii, 208 pp.

Language: English

Subjects: Ancient Philosoph Studies

Publisher: Brill

Series: Philosophia Antiqua

E-Book (PDF)

Released online: 21 Jun 2016

ISBN: 978-90-04-32075-8

List price

USD $\$ 98.00$

Hardback

Publication date: o1 Jan 1992

ISBN: 978-90-04-09429-1

List price

USD \$92.00 


\title{
Biographical Note
}

E.P. Bos is lecturer in Ancient and Medieval Philosophy of the University of Leiden. He has published on 14th century philosophy, especially on Marsilius of Inghen.

P.A. Meijer is lecturer in Ancient Philosophy of the same university, and has published on Plotinus and Proclus.

For more information see brill.com

\author{
Order information: Order online at brill.com \\ +44330 3330049 | customerservices@brill.com \\ Submission information: brill.com/authors
}

Titles published by Brill | Fink, Brill | mentis or Brill | Schöningh: +49(o)715413279216| brill@brocom.de 